\title{
Multimaterial Micro Injection Molding
}

\author{
Islam, Aminul
}

Publication date:

2018

Document Version

Publisher's PDF, also known as Version of record

Link back to DTU Orbit

Citation (APA):

Islam, A. (2018). Multimaterial Micro Injection Molding. Abstract from Micro Nano Molding Seminar, Book release \& Reception - Technology and Applications, Kgs. Lyngby, Denmark.

\section{General rights}

Copyright and moral rights for the publications made accessible in the public portal are retained by the authors and/or other copyright owners and it is a condition of accessing publications that users recognise and abide by the legal requirements associated with these rights.

- Users may download and print one copy of any publication from the public portal for the purpose of private study or research.

- You may not further distribute the material or use it for any profit-making activity or commercial gain

- You may freely distribute the URL identifying the publication in the public portal

If you believe that this document breaches copyright please contact us providing details, and we will remove access to the work immediately and investigate your claim. 


\title{
Contact info:
}

\section{Dr. Aminul Islam, Associate Professor}

Centre for Acoustic-Mechanical Micro Systems, Department of Mechanical Engineering, Technical University of Denmark Address: Produktionstorvet, Building 427A, Room 322, 2800 Kgs. Lyngby, Denmark

E-mail: $\underline{\text { mais@mek.dtu.dk }}$

Phone: + 4545254896

\section{Presentation Title: Multimaterial Micro Injection Molding}

\begin{abstract}
The continuous trend towards miniaturization and multi-functional products calls for more and more multimaterial components for the future micro systems. The multimaterial and functionally integrated products are becoming in most cases an economic and technological key factor for the advanced micro systems. One of the most industrially feasible ways to produce multicomponent micro parts is the multimaterial micro moulding. By merging of shaping and assembly processes into a single step in multimaterial (also known as multicomponent) moulding, a significant economic progress can be made in micro manufacturing. This presentation will focus on the different aspects of multimaterial micro injection moulding. Special emphasis will be given to the two component micro injection moulding as this is the basic process of multicomponent micro injection moulding. The challenging task for the two component moulding is to find a material pair which fulfils the diverse requirements for the engineering application and at the same time has a reasonably good bonding and sharp interface between the two polymer materials. Many fascinating applications of two component or multi component polymer parts are restricted due to the weak interfacial adhesion and interface quality of the polymers. A thorough understanding of the factors that influence the polymer-polymer bond strength and interface quality is extremely important for the success of multicomponent moulding. The presentation focuses on the parameters that influence the quality of polymer-polymer bonding, interface and analyses the relations between the bonding and the interface quality with the special focus on micro scale applications. The results and discussion presented in this talk will provide a guideline for the multicomponent micro moulding for a wide range of industrial applications.
\end{abstract}

Mini CV: Dr. Aminul Islam is working as an Associate Professor at the Center for Acoustic Mechanical Micro Systems (CAMM), Department of Mechanical Engineering, Technical University of Denmark (DTU). CAMM center is sponsored by three Danish hearing aid companies - Oticon, Widex, and GN Resound. Dr. Islam is a specialist in multimaterial micro manufacturing having 15 years of professional experiences with a unique mix of research experience both from industry and academia. He obtained his Ph.D. from Technical University of Denmark in the year 2008. His research interest comprises advanced material processing, multi-material micro moulding, micro powder moulding, moulded interconnect devices (MIDs), hearing aid technology \& components etc. He is the author and co-author of more than 70 peer-reviewed publications including journal articles, conference papers, and books.

\section{Photo:}

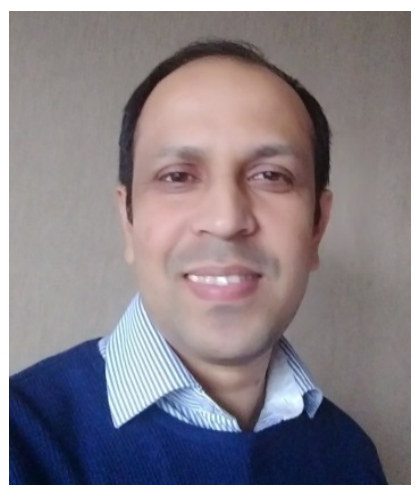




\section{Relevant illustrations:}
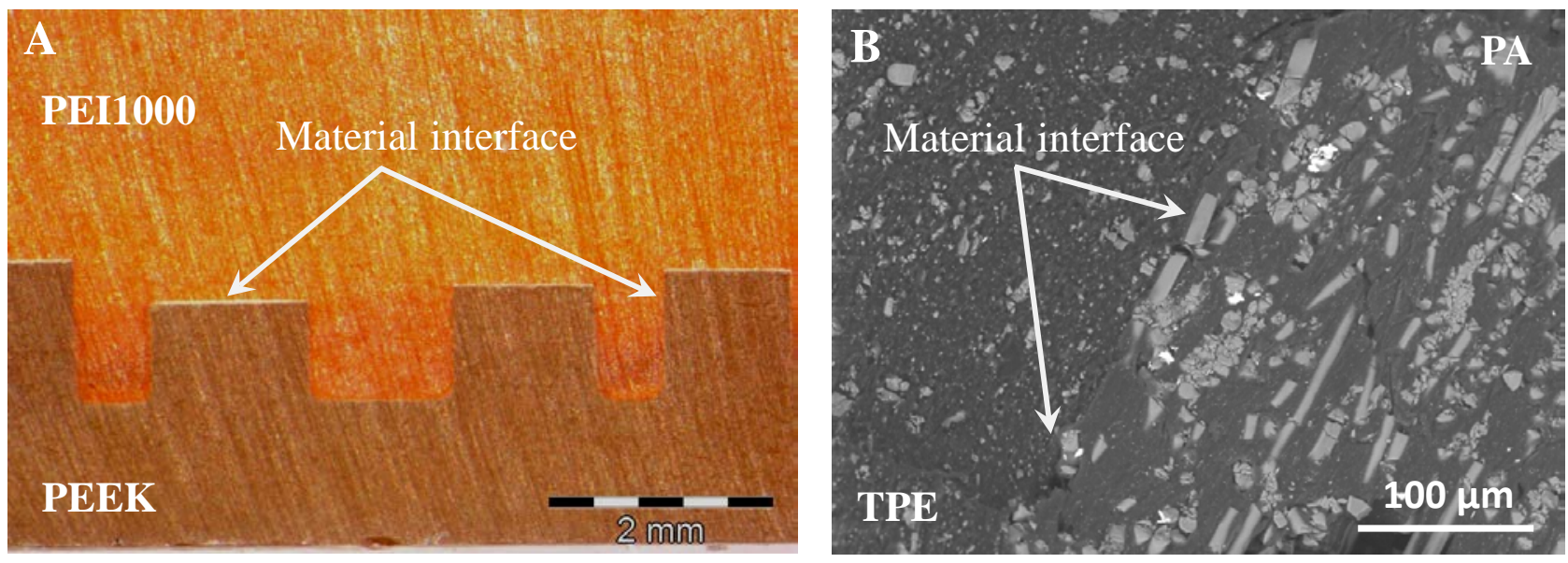

Fig: Pictures showing polymer-polymer interfaces: interface between two hard plastics (PEI100-PEEK)- picture $A$, interface between a hard and soft plastic (PA-TPE)- picture $B$. 